Research Article

\title{
Conflict Management Skills among Nursing Tutors Working in Nursing Colleges
}

\author{
Bindu Thapa $^{1 *}$, Amrita Poudel ${ }^{1}$, Deepti K.C ${ }^{1}$, Janaki Chaudhary² ${ }^{2}$ Kalpana Katel ${ }^{1}$, Sharmila \\ Poudel $^{2}$, Shreejana Shrestha ${ }^{1}$, Sunita Gurung ${ }^{1}$ \\ ${ }^{1}$ Adult Health Nursing, Gandaki Medical College Teaching Hospital and Research Centre (GMCTHRC), Nepal \\ ${ }^{2}$ Women Health, and Development, Gandaki Medical College Teaching Hospital and Research Centre (GMCTHRC), Nepal
}

\begin{tabular}{|c|c|}
\hline Article Information & Abstract \\
\hline $\begin{array}{l}\text { Received: } 28 \text { December } 2020 \\
\text { Revised version received: } 01 \text { March } 2021 \\
\text { Accepted: } 05 \text { March } 2021 \\
\text { Published: } 28 \text { April } 2021 \\
\text { Cite this article as: } \\
\text { B. Thapa et al. }(2021) \text { Int. J. Soc. Sc. Manage. } 8(2) \text { : } \\
\text { 359-361. DOI: 10.3126/ijssm.v8i2.33872 } \\
\text { *Corresponding author } \\
\text { Bindu Thapa, } \\
\text { Adult Health Nursing, Gandaki Medical College } \\
\text { Teaching Hospital and Research Centre } \\
\text { (GMCTHRC), Nepal } \\
\text { Email: binduthapa019@gmail.com } \\
\text { Peer reviewed under authority of IJSSM } \\
\text { () } 2021 \text { IJSSM, Permits unrestricted use under the } \\
\text { CC-By-NC license. } \\
\text { OPEN A ACCESS } \\
\text { This is an open access article \& it is licensed under a } \\
\text { Creative Commons Attribution Non-Commercial } 4.0 \\
\text { International } \\
\text { (https://creativecommons.org/licenses/by-nc/4.0/) }\end{array}$ & $\begin{array}{l}\text { Conflict can exist among individuals, educational institutions, organizations, } \\
\text { leadership of department, between staff, students and among tutors Conflict } \\
\text { management is the practice of being able to identify and handle conflicts sensibly, } \\
\text { fairly and efficiently. The objective of the study is to assess the conflict } \\
\text { management skills among nursing tutors working in nursing colleges. Descriptive } \\
\text { cross sectional research design was adopted for this study. Census method was used } \\
\text { to select the subjects. Data collection was done among } 74 \text { nursing tutors of Kaski } \\
\text { district. Data was collected by using self-administered Thomas Killman conflict } \\
\text { mode standardized tool. The study revealed that } 28.78 \% \text { use avoiding, } 20.58 \% \text { use } \\
\text { compromising, } 19.9 \% \text { use accommodating, and } 18.74 \% \text { collaborating and } 12 \% \text { use } \\
\text { competing as conflict management skill. Conclusion: Avoiding was most } \\
\text { commonly used conflict management style by nursing tutors whereas competing is } \\
\text { the least. }\end{array}$ \\
\hline Keywords: Conflict; Management Skills; Nursing; T & \\
\hline
\end{tabular}

\section{Introduction}

Conflict is a situation in which the conditions, practices or goals for the different participants are inherently incompatible (Corwin,1969). Conflict is a stage where people strive for their preferred outcome which if attained prevents others from achieving their own preferred outcome

thereby resulting in hostility and breakdown in human relation (Barry \& Reece, 2006)

In fact, conflict is a part and parcel of everyday life and each individual enters into some type of conflict in his/her life Conflict can exist among individuals, educational 
institutions, organizations, leadership of departments as well as conflicts can also exist between staff, students and among tutors. In educational institutions the consequences of such conflicts may be direct and indirect and they include employee grievances, diversion of management time and disruption of professional relationship, workplace aggression, and psychological aggression (Weaver, 2008).

Workplace conflict can also result from poor communication, lack of employee motivation and/or unequal treatment in terms of allocation of duties/responsibility and authority or in the distribution of benefits (Morrison, 2008).

Conflict management is the practice of being able to identify and handle conflicts sensibly, fairly and efficiently. Conflict can also be managed in different ways, some focusing on inter-personal relationship and other on structural changes. In western cultural concept such as Canada and USA conflict is managed by fostering communication among disputants, problem solving and drafting agreement that meet their underlying needs, a winwin solution (Hotepo et al., 2010)

Handling conflict can have a positive impact on patient care and safety. It can also boost up the staff morale and reduces anxiety among the nursing professionals. It can also reduce the burnout syndrome. Review of number of studies carried out in various settings has revealed that various modes of conflict management skills are used by the nurses. This includes avoiding, competing, collaboration, accommodating and compromising (Johansen, 2012).

Though a number of studies have focused in conflict management skills among various professionals, a few studies have been carried out in developing countries regarding conflict management skills among nurses. This type of study has not done in nursing colleges in Pokhara of Kaski district. Hence, the researchers are interested to find out the conflict management skills among nursing tutors working in nursing colleges of Pokhara.

\section{Methods}

Descriptive cross sectional research design was adopted for this study. Census method was used to select the subjects. Data collection was done in nursing tutors of nine nursing colleges of Pokhara which includes Pokhara Nursing Campus, Charak Academy of Health Sciences, Novel Academy, Pokhara University, School of Health and Allied Science, Pokhara Technical Health And Medical Institute, Manipal College of Health Sciences, Fewacity Nursing Campus, Fishtail Nursing Campus, Padma Nursing Home School of Nursing. Out of 100 nursing tutors, 74 responded. Self-administered Thomas Killman conflict mode standardized tool was used to collect data. The research instrument was divided into 2 parts:
Part I: Semi-structured questions related to social demographic variables.

Part II: Structured questions as measured by Thomas Killman conflict mode.

Thomas Killman conflict mode comprises 30 items (60statements). The instrument includes 12 statements of each five style of conflict management i.e. competing, collaborating, compromising, avoiding and accommodating.

Ethical clearance was taken from GMC, Institutional Review Committee of the college (GMC-IRC). Informed written consent was taken from each participant. Collected data was edited, coded and entered into Microsoft Excel and transferred into Statistical Package for Social Science (SPSS) version 20. The obtained data was analyzed by using descriptive method (mean, frequency, percentage).

\section{Results}

Table 1 shows that more than half $(59.5 \%)$ of respondents were from age group 31 to 40 years. All of the respondents were female and $82.4 \%$ were married. About two third of the respondents $(62.2 \%)$ completed master in nursing. Most of the respondents $(87.8 \%)$ follows Hinduism. More than half of the respondents $(56.8 \%)$ are lecturer. About one third of the respondents $(39.2 \%)$ had teaching experience of 3 to 6 years.

Table 1: Socio Demographic Characteristics of the Respondents

\begin{tabular}{|c|c|c|}
\hline Characteristics & Number & Percent \\
\hline \multicolumn{3}{|l|}{ Age in Completed Years } \\
\hline 20 to 30 years & 27 & 36.5 \\
\hline 31 to 40 years & 44 & 59.5 \\
\hline Above 41 & 3 & 4.1 \\
\hline \multicolumn{3}{|l|}{ Sex } \\
\hline Female & 74 & 100 \\
\hline Male & 0 & 0 \\
\hline \multicolumn{3}{|l|}{ Marital Status } \\
\hline Married & 61 & 82.4 \\
\hline Single & 13 & 17.6 \\
\hline \multicolumn{3}{|l|}{ Highest Educational } \\
\hline \multicolumn{3}{|l|}{ Qualification } \\
\hline $\begin{array}{l}\text { Masters in Nursing } \\
(\mathrm{MN} / \mathrm{MSc})\end{array}$ & 46 & 62.2 \\
\hline $\begin{array}{l}\text { Bachelor in Nursing } \\
\text { (BNS/BSc) }\end{array}$ & 28 & 37.8 \\
\hline \multicolumn{3}{|l|}{ Religion } \\
\hline Hindu & 65 & 87.8 \\
\hline Buddhist & 7 & 9.5 \\
\hline Christian & 1 & 1.4 \\
\hline Muslim & 1 & 1.4 \\
\hline \multicolumn{3}{|l|}{ Rank } \\
\hline Lecturer & 42 & 56.8 \\
\hline
\end{tabular}

Full text of this paper can be downloaded online at www.ijssm.org/ \& http://nepjol.info/index.php/IJSSM/issue/archive 
Table 1: Socio Demographic Characteristics of the Respondents

\begin{tabular}{cll}
\hline Characteristics & Number & Percent \\
\hline Instructor & 24 & 32.4 \\
Teaching Assistant & 6 & 8.1 \\
Others & 2 & 2.7 \\
Teaching Experience & & \\
$\quad$ <3 years & 27 & 36.5 \\
3 to 6 years & 29 & 39.2 \\
>6 years & 18 & 24.3 \\
\hline
\end{tabular}

\section{Nursing Tutors' Conflict Management Skills}

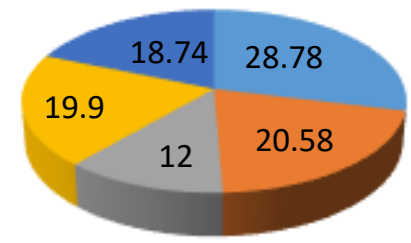

Avoiding

Compromising

Competing

Collaborating

Accomodating

Fig. 1: Nursing tutors' conflict management skills percentage.

Among 74 participants, 28.78\% use avoiding, 20.58\% use compromising, $19.9 \%$ use accommodating, $18.74 \%$ collaborating and $12 \%$ use competing as conflict management skill (Fig. 1).

\section{Discussion}

In this study the most common conflict management style used by nursing tutors was avoiding $(28.78 \%)$ which was followed by compromising $(20.58 \%)$. The study done among professional nurses in Madrid, Spain revealed that compromising was commonly used style to deal with workplace conflicts (Williams, 2005).

Similarly, another study finding concluded that accommodation style was commonly used for conflict resolution among nurses in clinical area and academic area (Thomas \& Saroj, 2015)

This study finding is in consistent with the findings of the study done in pediatric hospitals in Greece and in public hospitals in Cyprus among health-care personnel, where avoidance was found to be the most frequent mode chosen for conflict management (Kaitelidou et al., 2012)

Compromising as a conflict management style was preferred as second style by nursing tutors which is quite similar to the finding of the study performed among nurse managers in the nine Ministry of Health referral hospital, Jordan (Pavlakis,et al., 2011)

\section{Conclusion}

Based on the findings of the study out of 5 different conflict management styles (Competing, Collaborating, Compromising, Avoiding and Accommodating) avoiding was most commonly used style by nursing tutors in selected Nursing Colleges of Kaski district which was followed by compromising. The least preferable conflict management style among nursing tutors was competing.

\section{Acknowledgement}

Researchers would like to express sincere gratitude to all the respondents.

\section{References}

Barry L and Reece RB (2006) Effective Human Relations. Personal and Organizational Applications: Bost Houghton Mifflin Company

Corwin RG (1969) Patterns of Organizational Conflict. Administrative Science Quarterly 14(4): 507-520.

Hotepo OM, Asokere AS, Azeez A and Ajemunigbohun SSA (2010) Empirical study of the effect of conflict on organizational performance in Nigeria. Business and Economic Journal 2(9): 123-129.

Jehn K, Greer L, Levine S and Szulanski G (2008) The effects of conflict types, dimensions, and emergent states on group outcomes. Group Decision and Negotiation 17(6): 465495.

Johansen ML (2012) Keeping the peace: Conflict management strategies for nurse managers. Nursing Management 43(2): 50-54.

Kaitelidou D, Kontogianni A, Galanis P, Siskou O, Mallidou A, Pavlakis A, Kostagiolas P, Theodorou M and Liaropoulos L (2012) Conflict management and job satisfaction in paediatric hospitals in Greece. Journal of nursing management 20(4): 571-578.

Morrison J (2008) The relationship between emotional intelligence competencies and preferred conflict-handling styles. Journal of Nurs Manag 16(8): 974-983.

Pavlakis A, Kaitelidou D, Theodorou M, Galanis, Sourtzi P and Siskou O (2011) Conflict management in public hospitals: the Cyprus case. International Nursing Review 58(2): 242248.

Thomas C and Saroj LM (2015) Identify Conflict Resolution Styles used by Nursing Professionals working in Clinical and Academic settings of selected Hospitals and Nursing Colleges of Southwestern Rajasthan. International Journal of Advances in Nursing Management 3(3): 273277.

Weaver TD, Roseman CC and Stringer CB (2008) Close correspondence between quantitative-and moleculargenetic divergence times for Neandertals and modern humans. Proceedings of the National Academy of Sciences 105(12): 4645-4649.

Williams N (2005) Workplace Violence: Issues, Trends, Strategies. Occupational Medicine 56(6): 434. 